\title{
The potential for an outbreak of glanders in Nepal
}

\author{
Niran Adhikari ${ }^{1^{*}}$ (D), Krishna Prasad Acharya ${ }^{2}$ and Richard Trevor Wilson ${ }^{3}$
}

\begin{abstract}
Confirmation of glanders has not been possible in suspected cases submitted by field veterinarians, mainly due to the lack of diagnostic tools in Nepal. In view, however, of the re-emergence of glanders in India and the unrestricted migration of equines from there in to Nepal, an outbreak of Glanders in the short term is a distinct possibility. Such an event would affect the rural, marginalized community, and brick kiln industries. Therefore, due attention on the national epidemiological study and strengthened animal quarantine system with holding yards and laboratory backups are highly requested. Besides, the government's timely action on disease prevalence, monitoring, and disease reporting is utmost important besides widespread public awareness to prevent the entry and control the disease.
\end{abstract}

Keywords: Equine diseases, Farcy, Burkholderia mallei, Mallein test, Re-emerging diseases

Glanders or farcy is a rare, contagious, infectious zoonotic disease that is caused by the bacterium Burkholderia mallei [1]. It mainly affects horses, mules, and donkeys. The late fifteenth-century French "glandres" and various other historical names underline the former importance of this disease. Symptoms include nasal discharge, pneumonia, and ulcerating nodular lesions on the skin. The disease is transmitted via contaminated feed, water, and meat. It is mainly reported from areas where equids are housed under unhygienic, overcrowded, and stressful environments with practices of sharing grooming equipment, water holes, and grazing areas [2]. Glanders used to be global problem but was later eradicated from Europe, North America, and Australia by collaboration among governments and other agencies. Glanders has regained global attention as a re-immerging disease with confirmed cases from Bahrain, Germany, [3, 4] and various parts of India [5].

The first confirmed case of glanders in equines in India was in 1913 and was later reported from several areas before being brought under control [6]. Glanders was re-introduced to India in 1962 with the import of unscreened equines during the Indo-Chinese war. $\mathrm{Nu}$ merous cases have since been reported [2]. Glanders reappeared in Maharashtra State in July 2006 and has

\footnotetext{
* Correspondence: adhikari.niran16@gmail.com

${ }^{1}$ Animal Health Training \& Consultancy Services, Pokhara, Nepal

Full list of author information is available at the end of the article
}

subsequently been reported in several states. In the period 2006-2017, the disease's outbreak increased by more than 100\%. [5] (Table 1). Uttar Pradesh, from which most equines and most of immigrant laborers arrive in Nepal [7], recorded the highest number of Glanders outbreaks (Fig. 1) with significant records during March-July (Table 1) [5] which coincides with the months of the greatest number of horse imports to Nepal [8]. No confirmed cases of glanders have so far been identified but the threat of the disease being introduced is very real in view of the weak surveillance and animal quarantine activities.

Glanders was listed as one of the contagious diseases of equines (B209) in the Animal Health and Livestock Services Act, 2055 [9] after which quarantine offices were established. In 2019, Nepal has eight quarantine offices and 29 animal quarantine check-posts. The annual report of the Central Animal Quarantine Office indicates that Nepal imported 2690 equines from India in 2073/74 the year AD 2017. Most equines imported from India passed through the Nepalgunj quarantine office, the closest to India's Uttar Pradesh region. Quarantine officers can prohibit entry of animal from such disease outbreak regions but poor coordination with Indian quarantine check posts, lack of animal holding yards, and illegal migration through the open border create problems for the Nepalese quarantine service.

(c) The Author(s). 2019 Open Access This article is distributed under the terms of the Creative Commons Attribution 4.0 International License (http://creativecommons.org/licenses/by/4.0/), which permits unrestricted use, distribution, and reproduction in any medium, provided you give appropriate credit to the original author(s) and the source, provide a link to the Creative Commons license, and indicate if changes were made. The Creative Commons Public Domain Dedication waiver (http://creativecommons.org/publicdomain/zero/1.0/) applies to the data made available in this article, unless otherwise stated. 
Table 1 Recorded number of Glanders outbreak in India, 2006-2017

\begin{tabular}{|c|c|c|c|c|c|c|c|c|c|c|}
\hline \multirow[t]{2}{*}{ Month } & \multicolumn{10}{|l|}{ Year } \\
\hline & 2006 & 2007 & 2008 & 2009 & 2010 & 2011 & 2012 & 2015 & 2016 & 2017 \\
\hline January & & & & & & $3(U)$ & & & $1(\mathrm{G})$ & $1(J)+1(U)$ \\
\hline February & & & & & & & & & $1(J)$ & $1(J)+3(U)$ \\
\hline March & & & & & $1(\mathrm{C})$ & & $1(U)$ & $1(H)+1(J)$ & $4(G)+1(J)$ & $1(J)+1(G)+4(U)$ \\
\hline April & & +()$(W)$ & +()$(W)$ & +()$(W)$ & & & & & & $8(U)$ \\
\hline May & & & & & & & & & $1(J)$ & $1(J)+1(G)+2(M)+9(U)$ \\
\hline June & & & & & $1(H)$ & & & & $1(J)$ & $1(J)+13(U)+2(R)$ \\
\hline July & $2(\mathrm{M})$ & & & & & & & & $1(J)$ & $6(U)+1(M)$ \\
\hline August & & & & & & & & & & $9(U)$ \\
\hline September & & & & & +()$(W)$ & +()$(W)$ & & & & $21(U)+1(R)$ \\
\hline October & & & & & & & & & & $3(\mathrm{M})+1(\mathrm{~J})$ \\
\hline November & & & & & & & & & & $10(U)+1(J)$ \\
\hline December & & & & & & & & & & $5(U)$ \\
\hline
\end{tabular}

+ (): Disease limited to one or more zones, G Gujarat, C Chhattisgarh, $H$ Himachal, J Jammu \& kashmir, $M$ Maharastrha, $R$ Rajasthan, $U$ Uttarpradesh, $W$ Whole Country

Nepal's Central Veterinary Laboratory (CVL) is the national veterinary reference laboratory. Samples from suspicious imported animals are dispatched to the CVL for analysis [10]. In 2071/72 (AD 2014), CVL conducted epidemiological investigations and surveillance of animal diseases but does not have the facility to test for glanders [11]. The guidelines of the World Organization for Animal Help (Office International des Epizooties, OIE) state that a standard cultural and serological test is required for glanders [12]. The Complement Fixation Test (CFT) has a sensitivity of $91.4 \%$, a specificity of $100 \%$ and an accuracy of $96.7 \%$. It can detect glanders in both clinically unapparent carriers and chronically infected equines but is incompetent with anti-complementary equine serum [13]. Unfortunately, its high cost means it is less affordable as a screen test for low-income countries such as Nepal.

Isolation and identification of $B$. mallei isolation requires a bio-safety level 3 (BSL3) laboratory [14, 15]. The National Public Health Laboratory (NPHL) is the only BSL3 laboratory in Nepal but largely confines itself to human diseases [16]. Possible tests for glanders are the culture test but this is negative before death in the septicemic form of the disease. The Mallein test is simple, has a sensitivity of $75.57 \%$, a specificity of $100 \%$ and an accuracy of $90.6 \%$ [13], but is less efficient in

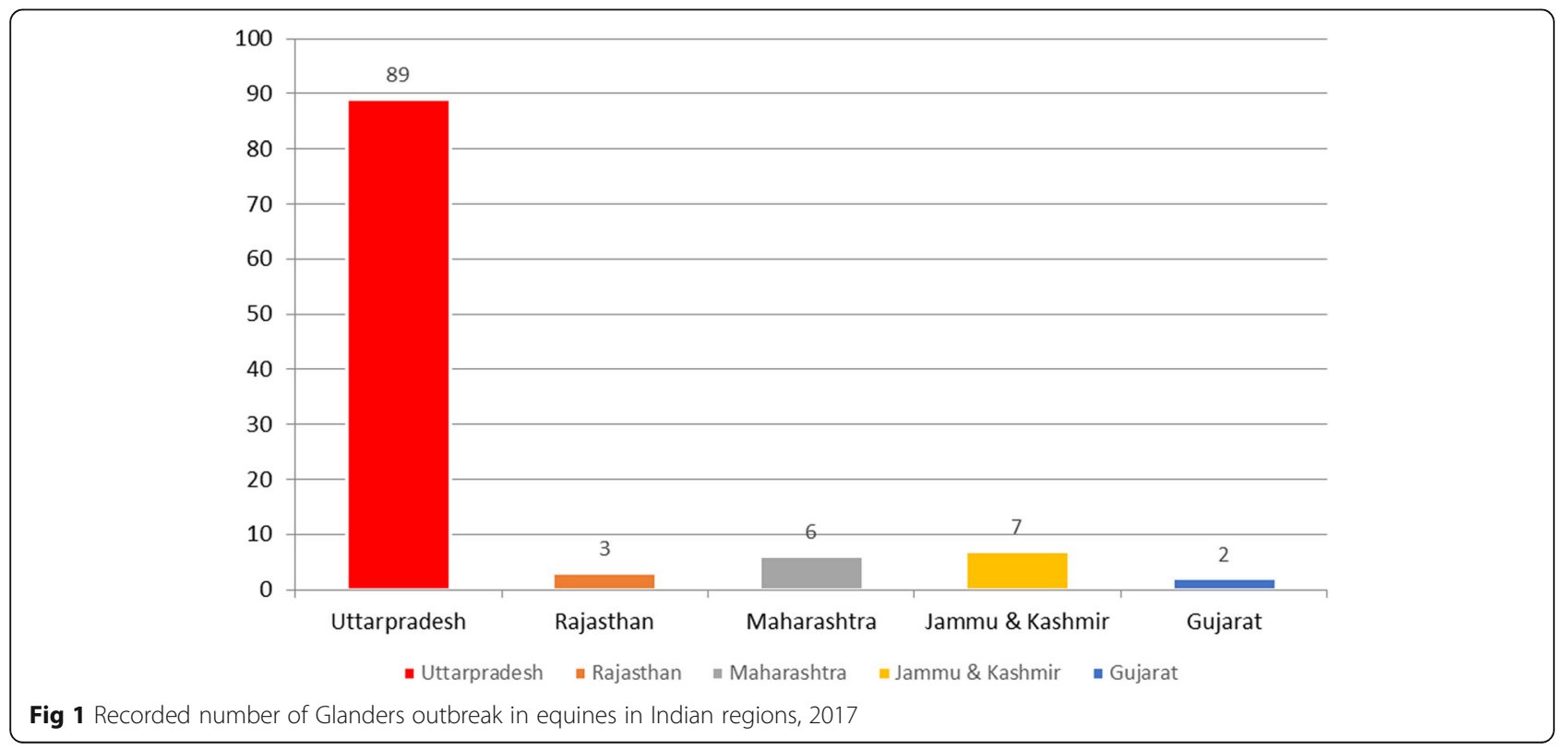


clinically advanced cases poor competence in technicians may cause injury and blindness to the animal. The Rose Bengal test (RBT) is another similar affordable screening test with a sensitivity of $90 \%$, a specificity of $100 \%$ and an accuracy of: $96.1 \%$ [13], but unlike the Mallein test, it is more potent in cases of non-response or advanced glanders [17]. The best approach to identification of glanders in Nepal would appear to be a Mallein or RBT test as a screen test at quarantine check posts and CFT as confirmative diagnosis at the CVL.

Equines have contributed to human welfare and people's livelihoods in Nepal since time immemorial. Horses especially, but also donkeys and mules, are a major means of transport in rural areas. They are also used by the Nepalese Army and Police Force and are a major component of the brick-making industry in southern Nepal [18] where more than 2200 animals of the 56,834 Nepali equine populations work [19]. Brick-making is one of the largest employers of human labor in the country. An outbreak of glanders would thus have an enormous negative impact not only on the horses but also on the poor people who work with them and have no possibility of other forms of employment [7].

\section{Conclusion}

Consequent on the re-emergence of Glanders in India and periodic unrestricted migration of equines from there and especially from Uttar Pradesh neighboring on Nepal an outbreak of Glanders in Nepal is a distinct possibility. Such an outbreak would have an adverse impact not only on Nepal's equine population but also on the welfare and livelihoods of a large number of poor families and especially those working in the brick-making industry. More attention by government to the disease is warranted. Quarantine offices should keep full records of equines imported from outbreak regions in and possibly prohibit such entry. Where equines are allowed entry effective short-term measures to prevent or control glanders would be screening of imported animals with the Mallein or RBT test at quarantine check posts followed by a CFT test at the CVL. The long-term goal should be to improve coordination between quarantine offices on both sides of the border zone, enforce stringent quarantine measures, test for glanders in resident equines in Nepal, euthanasia positive glanders cases, and create greater awareness by the general public of the disease and its potential impact through specific campaign and in the media.

\section{Abbreviations}

BSL3: Bio-safety level 3; CFT: Complement fixation test; CVL: Central Veterinary Laboratory; NPHL: National Public Health Laboratory; OIE: Office International des Epizooties; RBT: Rose Bengal test

\section{Acknowledgements}

Dr. Dinesh Mohite and Kshitiz Shrestha commented on an earlier version of the manuscript.

\section{Authors' contributions}

NA developed the concept for the paper, made a literature review, wrote the first draft, and revised the manuscript. KPA and RTW thoroughly reviewed and revised the manuscript, checked the references, and edited this version in collaboration with NA. All authors have read and approved the final manuscript.

Funding

No external funding was used in the preparation of this paper.

\section{Availability of data and materials}

The datasets generated and/or analyzed during the current study are available in the OIE World Animal Health Information System repository, https://www.oie.int/wahis_2/public/wahid.php/Diseaseinformation/statusdetail. Accessed 23 Sep 2019.

Ethics approval and consent to participate

Not applicable (NA).

Consent for publication

Not applicable (NA).

\section{Competing interests}

The authors declare that they have no competing interests.

\section{Author details}

${ }^{1}$ Animal Health Training \& Consultancy Services, Pokhara, Nepal. ${ }^{2}$ Animal Quarantine Office (AQO), Budhanilkantha, Kathmandu, Nepal. ${ }^{3}$ Bartridge House, Umberleigh, UK.

Received: 2 August 2019 Accepted: 6 November 2019

Published online: 11 December 2019

\section{References}

1. Khan I, Wieler LH, Melzer F, Gwida M, Santana VL, de Souza MMA, et al. Comparative evaluation of three commercially available complement fixation test antigens for the diagnosis of glanders. Vet Rec. 2011;169:495. https://doi.org/10.1136/vr.d5410.

2. Verma AK, Saminathan M, Neha TR, Dhama K, Singh SV. Glanders-a reemerging zoonotic disease: a review. J Biol Sci. 2014;14:38-51. https://doi. org/10.3923/jbs.2014.38.51.

3. Elschner MC, Thomas P, Melzer F. Complete genome sequence of a Burkholderia mallei isolate originating from a glanderous horse from the Kingdom of Bahrain. Genome Announc. 2016;4. https://doi.org/10.1128/ genomeA.01296-16.

4. Scholz HC, Pearson T, Hornstra H, Projahn M, Terzioglu R, Wernery R, et al. Genotyping of Burkholderia mallei from an outbreak of glanders in Bahrain suggests multiple introduction events. PLoS Negl Trop Dis. 2014;8. https:// doi.org/10.1371/JOURNAL.PNTD.0003195.

5. OIE World Animal Health Information System. https:/www.oie.int/wahis_2/ public/wahid.php/Diseaseinformation/statusdetail. Accessed 23 Sep 2019.

6. Malik P, Singha H, Goyal SK, Khurana SK, Tripathi BN, Dutt A, et al. Incidence of Burkholderia mallei infection among indigenous equines in India. Vet Rec open. 2015;2:e000129. https://doi.org/10.1136/vetreco-2015-000129.

7. (PDF) Brick by Brick: Unveiling the full picture of South Asia's brick kiln industry and building the blocks for change | Dakhina Mitra - Academia. edu. https://www.academia.edu/37267025/Brick_by_Brick_Unveiling_the_ full_picture_of_South_Asias_brick_kiln_industry_and_building_the_blocks_ for_change. Accessed 23 Sep 2019.

8. Equus | Nepali Times Buzz|Nepali Times. https://archive.nepalitimes. com/article/Nepali-Times-Buzz/Equus-in-brick-kilns-kathmandu, 4085 . Accessed 23 Sep 2019

9. Animal Health and Livestock Services Act, 2055 (1999) - Nepal Law Commission. http://www.lawcommission.gov.np/en/wp-content/ uploads/2018/10/animal-health-and-livestock-services-act-2055-1999.pdf Accessed 23 Sep 2019.

10. Central Animal Quarantine Office: Annual Report 2073/74. http://caqo.gov. np/uploads/files/Annual_Report_2073_2074.pdf. Accessed 23 Sep 2019.

11. Central Veterinary Laboratory. http://www.cvl.gov.np/uploads/files/532482 0354.pdf. Accessed 23 Sep 2019. 
12. Access online: OIE - World Organisation for Animal Health. https://www.oie. int/standard-setting/terrestrial-manual/access-online/. Accessed 23 Sep 2019.

13. Naureen A, Saqib M, Muhammad G, Hussain MH, Asi MN. Comparative evaluation of Rose Bengal plate agglutination test, Mallein test, and some conventional serological tests for diagnosis of equine glanders. J Vet Diagnostic Investig. 2007;19:362-7. https://doi.org/10.1177/ 104063870701900404.

14. Kinoshita Y, Cloutier AK, Rozak DA, Khan MSR, Niwa H, Uchida-Fujii E, et al. A novel selective medium for the isolation of Burkholderia mallei from equine specimens. BMC Vet Res. 2019;15:133. https://doi.org/10.1186/s12917-019-1874-0.

15. Burkholderia Mallei and Pseudomallei (Glanders and Melioidosis). http:// www.centerforhealthsecurity.org/our-work/publications/glanders-andmelioidosis-fact-sheet. Accessed 23 Sep 2019.

16. NPHL | Pages. https://www.nphl.gov.np/page/about. Accessed 23 Sep 2019.

17. Karimi A, Mosavari N. Development of Rose Bengal test against mallein test for rapid diagnosis of equine glanders. Trop Anim Health Prod. 2019;51: 1969-74. https://doi.org/10.1007/s11250-019-01890-6.

18. Sustainable Equine Welfare through Improved Human Behavior and Working Environment | ANIMAL HEALTH TRAINING AND CONSULTANCY SERVICE (AHTCS). https://www.ahtcs.org.np/2017/01/22/working-equinewelfare-project-wewp/. Accessed 23 Sep 2019

19. OIE World Animal Health Information System. https://www.oie.int/wahis_2 public/wahid.php/Countryinformation/Animalpopulation. Accessed 23 Sep 2019.

\section{Publisher's Note}

Springer Nature remains neutral with regard to jurisdictional claims in published maps and institutional affiliations.

Ready to submit your research? Choose BMC and benefit from:

- fast, convenient online submission

- thorough peer review by experienced researchers in your field

- rapid publication on acceptance

- support for research data, including large and complex data types

- gold Open Access which fosters wider collaboration and increased citations

- maximum visibility for your research: over $100 \mathrm{M}$ website views per year

At $\mathrm{BMC}$, research is always in progress.

Learn more biomedcentral.com/submissions 